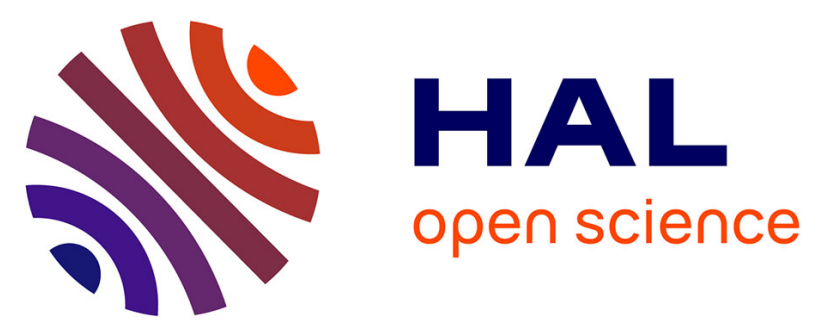

\title{
Anthropogenic lead distribution in soils under arable land and permanent grassland estimated by $\mathrm{Pb}$ isotopic compositions
}

Christelle Fernandez, Fabrice Monna, Jérôme Labanowski, Michel Loubet, Folkert F. van Oort

\section{To cite this version:}

Christelle Fernandez, Fabrice Monna, Jérôme Labanowski, Michel Loubet, Folkert F. van Oort. Anthropogenic lead distribution in soils under arable land and permanent grassland estimated by $\mathrm{Pb}$ isotopic compositions. Environmental Pollution, 2008, 56 (3), pp.1083-1091. 10.1016/j.envpol.2008.04.014 . hal-02665959

\section{HAL Id: hal-02665959 \\ https: / hal.inrae.fr/hal-02665959}

Submitted on 31 May 2020

HAL is a multi-disciplinary open access archive for the deposit and dissemination of scientific research documents, whether they are published or not. The documents may come from teaching and research institutions in France or abroad, or from public or private research centers.
L'archive ouverte pluridisciplinaire HAL, est destinée au dépôt et à la diffusion de documents scientifiques de niveau recherche, publiés ou non, émanant des établissements d'enseignement et de recherche français ou étrangers, des laboratoires publics ou privés. 


\title{
Anthropogenic lead distribution in soils under arable land and permanent grassland estimated by $\mathrm{Pb}$ isotopic compositions
}

\author{
C. Fernandez ${ }^{\mathrm{a}}$, F. Monna ${ }^{\mathrm{b}}$, J. Labanowski $^{\mathrm{a}, \mathrm{c}}$, M. Loubet $^{\mathrm{d}}, \mathrm{F}$. van Oort $^{\mathrm{a}, *}$ \\ a INRA, UR 251-PESSAC, RD 10, F-78026 Versailles Cedex, France \\ ${ }^{\mathrm{b}}$ UMR 5594, CNRS, Université de Bourgogne, ARTéHIS, Centre des Sciences de la Terre, Bat. Gabriel, F-21000 Dijon, France \\ ${ }^{\mathrm{c}}$ UMR 6008, CNRS, Université de Poitiers, ESIP, Laboratoire de Chimie et Microbiologie de l'Eau (ex LCEE), 40 Avenue du Recteur Pineau, F-86022 Poitiers, France \\ d UMR 5563, Université Paul Sabatier, Laboratoire de Géochimie, 38 Rue des 36 Ponts, F-31400 Toulouse, France
}

Incorporation and distribution of airborne $\mathrm{Pb}$ in soils are related to agricultural management.

\section{A R T I C L E I N F O}

\section{Article history:}

Received 13 December 2006

Received in revised form 18 April 2008

Accepted 27 April 2008

\section{Keywords:}

Metal pollution

Land use

$\mathrm{Pb}$ isotopic compositions

Anthropogenic $\mathrm{Pb}$

Lanthanum

\begin{abstract}
A B S T R A C T
The role of land use on fate of metals in soils is poorly understood. In this work, we studied the incorporation of lead in two neighboring soils with comparable pedogenesis but under long-term different agricultural management. Distributions of anthropogenic $\mathrm{Pb}$ were assessed from concentrations and isotopic compositions determined on bulk horizon samples, systematical 5-10 cm increment samples, and on 24-h EDTA extracts. Minor amounts of anthropogenic lead were detected until 1-m depth under permanent grassland, linked to high earthworm activity. In arable land, exogenous $\mathrm{Pb}$ predominantly accumulated at depths $<60 \mathrm{~cm}$. Although the proximity between the two sites ensured comparable exposition regarding atmospheric $\mathrm{Pb}$ deposition, the isotopic compositions clearly showed the influence of an unidentified component for the cultivated soil. This work highlights the need for exhaustive information on historical human activities in such anthropized agrosystems when fate of metal pollution is considered.
\end{abstract}

(c) 2008 Elsevier Ltd. All rights reserved.

\section{Introduction}

Anthropogenic atmospheric emissions represent a major way for metal input in soils (Hernandez et al., 2003; Watmough and Hutchinson, 2004). In polluted areas, contrasting situations over short distances may be observed since airborne contaminated particles are variably intercepted by the plant cover (Jensen and Svensmark, 1989; Blum et al., 1997; van Oort et al., 2001), and because metals may be partially exported by harvesting. After incorporation and alteration of metal-bearing particles in soils, mobility of released metals in the soil solution largely depends not only on physicochemical soil parameters, such as $\mathrm{pH}, \mathrm{CEC}$, and porosity, but also on the amount and nature of reactive metaltrapping soil constituents (Teutsch et al., 2001; Hernandez et al., 2003). Fate of metals in soils seems therefore closely linked to land use and related agricultural practices (liming, fertilization, plowing), which may markedly influence soil characteristics and behavior (Andersen et al., 2002; Fernandez et al., 2007).

Studies focusing on lead pollution in soils under various field conditions most often reveal a predominant $\mathrm{Pb}$ accumulation in

\footnotetext{
* Corresponding author.

E-mail address: vanoort@versailles.inra.fr (F. van Oort).
}

surface horizons, underlining to its low-mobile character. Limited but nonetheless marked downward migrations, representing potential long-term risks for groundwater, were, however, observed (Emmanuel and Erel, 2002; Citeau et al., 2003; van Oort et al., 2006). Evidence for lead migration in the soil profile is frequently assessed by comparing $\mathrm{Pb}$ concentrations at different depths, or by examining the penetration of anthropogenic lead, which may be estimated using linear regression between trace and major elements (Sterckeman et al., 2000; Fernandez et al., 2007; Lamy et al., 2006). Alternatives have been developed using sequential and/or specific chemical extractions (Abollino et al., 2002; Kabala and Szerszen, 2002). These different approaches led to growing comprehension of lead migration in soils. However, minor variations in metal concentrations may be observed along the soil profile due to a variable mineralogical composition (e.g. clay illuviation horizons), and hence be erroneously ascribed to the migration of an anthropogenic component. In addition, minor accumulation of anthropogenic $\mathrm{Pb}$ may be overlooked in deeper soil horizons because of the predominant occurrence of endogenous $\mathrm{Pb}$ at these depths (van Oort et al., 2006). The use of lead isotopic compositions was shown useful to palliate these problems. Briefly, anthropogenic emissions reflect the isotopic compositions of the geological sources of lead. In Western Europe, this signature most often differs from that of natural lead 
(Monna et al., 1998; Véron et al., 1999; Hansmann and Köppel, 2000). Consequently, $\mathrm{Pb}$ isotopes act as fingerprints enhancing the discrimination of anthropogenic vs. the endogenic lead pools. Details on methods and fundamentals are available in several studies on $\mathrm{Pb}$ isotopes in soils (Erel et al., 1990; Teutsch et al., 2001; Haack et al., 2003; Ettler et al., 2004; Farmer et al., 2005).

The influence of land use on the incorporation and distribution of anthropogenic $\mathrm{Pb}$ in soils is poorly documented. The present work aimed to assess the role of agricultural management on the incorporation of industrial atmospheric lead deposition in soils. For this, a paired soil plot was selected at almost equal distance from a $\mathrm{Pb}$-emitting source. The soils were developed under comparable site conditions, but managed under continuous different land use for about one century (Fernandez et al., 2007). After detailed analyses of $\mathrm{Pb}$ concentrations performed on bulk samples from soil horizons and on 5-10 cm increment samples until 1-m soil depth, the anthropogenic $\mathrm{Pb}$ distribution was estimated using several scenarii, including normalization with respect to thorium and/or lanthanum. Distributions of potentially mobile lead were also estimated from 24-h EDTA extractions performed on bulk samples from horizons. EDTA extractions were used since they were shown to remove preferentially anthropogenic lead among the overall $\mathrm{Pb}$ pool in soils (Bacon and Hewitt, 2005; Komárek et al., 2006). Pb isotope analyses were systematically performed on all soil samples and on EDTA extraction solutions. Results were compared to assess the distribution, migration and origin of $\mathrm{Pb}$ in soils under different land use.

\section{Materials and methods}

\subsection{Site and soil conditions}

\subsubsection{Pollution history}

The study site is located in the NE part of the alluvial plain of Scarpe-Escaut close to the Belgium border (Northern France, Fig. 1), about $15 \mathrm{~km}$ away from Valenciennes (40,000 inhab.), the nearest main city. This area was affected between 1902 and the 1960s by industrial fallout of $\mathrm{Zn}, \mathrm{Pb}, \mathrm{Cd}$, and to a lesser extent $\mathrm{Cu}$, generated

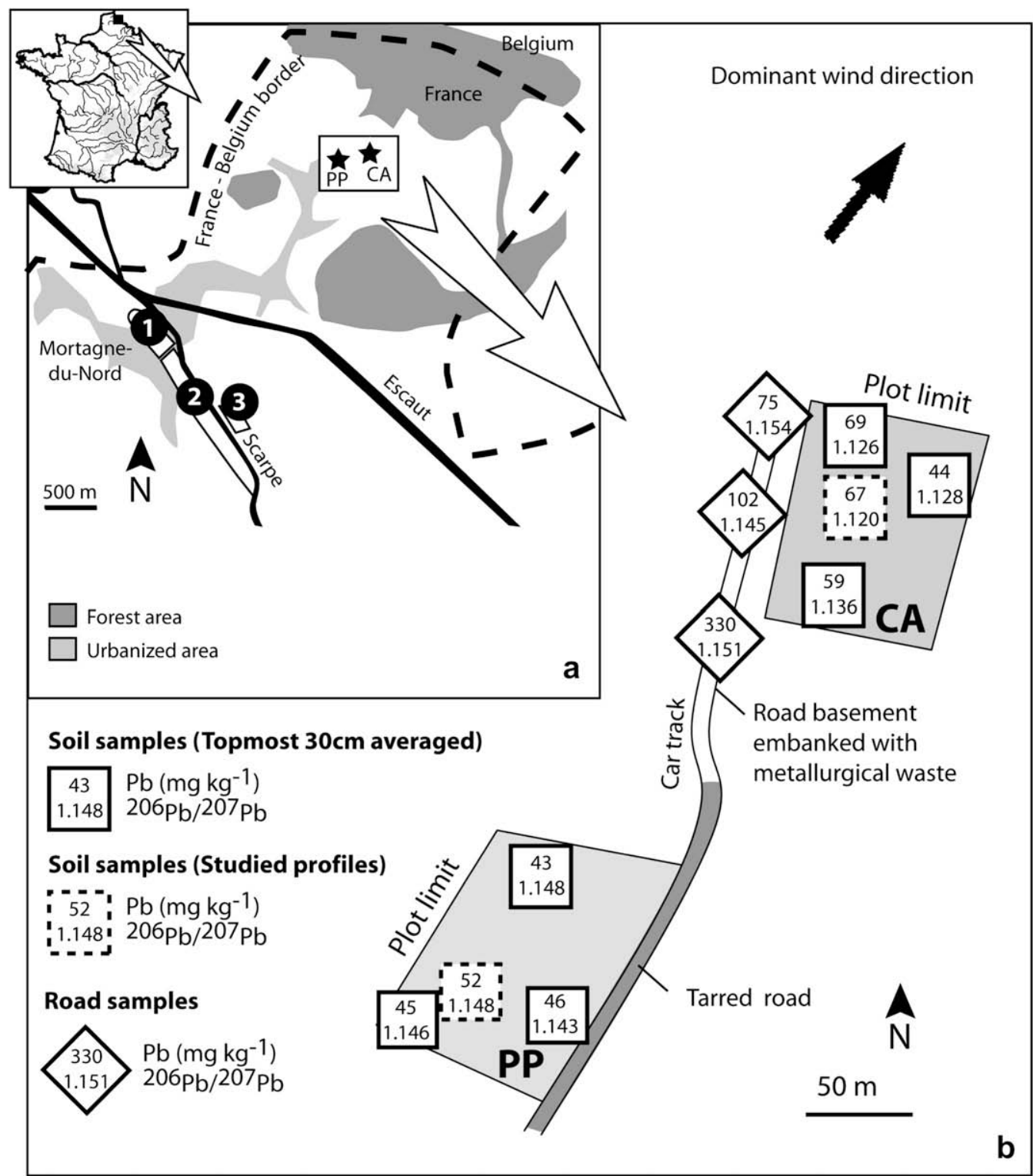

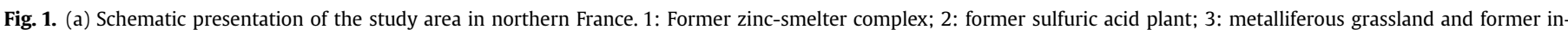

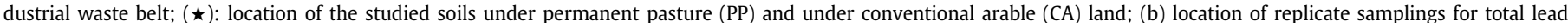
concentrations and ${ }^{206} \mathrm{~Pb} /{ }^{207} \mathrm{~Pb}$ isotope ratios performed in the PP and CA plots and in the car track. 
by major metallurgical activity of a zinc-smelter complex located at Mortagne-duNord. This activity led to a severe metal pollution of the 20-ha industrial site, estimated to reach $\sim 19,000 \mathrm{t}$ of metals (Thiry et al., 2002). In soils of the surrounding 5000-ha, including mainly agricultural and forest land, contamination by $\mathrm{Zn}, \mathrm{Pb}, \mathrm{Cd}$, and $\mathrm{Cu}$ issued by the activity of this metallurgical plant was estimated to be at least $12,000 \mathrm{t}$ (van Oort et al., in press). An exhaustive mineralogical and geochemical study on the industrial site (Thiry et al., 2002) showed that sulfides were the dominant form of emitted metals (sphalerite-ZnS, galena-PbS), highly unstable in alternating oxidation and reduction conditions prevailing in soils. In plow layers of agricultural soils, coarse sand-sized grains of industrial waste were occasionally identified (van Oort et al., 2002; Leguédois et al., 2004) with crystallized secondary metal-bearing phases: i.e. high-temperature silicates (hardystonite $\left(\mathrm{Ca}_{2} \mathrm{Zn}_{2} \mathrm{Si}_{2} \mathrm{O}_{7}\right)$, and secondary spinels (franklinite $(\mathrm{Zn}, \mathrm{Mn})(\mathrm{Fe})_{2} \mathrm{O}_{4}$, gahnite $\left.(\mathrm{Zn}) \mathrm{Al}_{2} \mathrm{O}_{4}\right)$. Except for this factory, no main motorway or other important industry within a 10-km radius occurs.

\subsubsection{Soil selection and characteristics}

Based on detailed previous study on distribution of metal pollution generated by this metallurgical activity (van Oort et al., 2001, 2002, in press), a paired soil site was selected at about $3 \mathrm{~km}$ from the former industrial site (Fig. 1a). The distance between the two study soils was less than $300 \mathrm{~m}$ (Fig. 1b). Both soils developed under comparable topographical and drainage conditions in a Tertiary marine Ostricourt sand cover forming a gently sloping relief. Some selected physicochemical data of both soils are presented in Table 1. Soil formation at the end of the Pleistocene and during the Holocene gave rise to development of Eutric Cambisols (FAO, 1998) in loamy sand textured material overlying a more clay-iron rich Cg2 horizon with clay illuviation features dating from periglacial activity (Fernandez et al., 2007), occurring generally at about $80-\mathrm{cm}$ depth. The two soils were supposed under comparable agricultural management at the end of the 19th century. As early as the beginning of the 20th century, concurrent with the starting of Zn-smelting activity, both soils were continuously under different land use. According to local enquiries, the first soil was managed under permanent pasture (PP, Fig. 1b), un-plowed during the last 100 years. They received mainly manure and little mineral fertilization. The second soil was under continuous conventional arable (CA) land use for cereal production. The surface horizon of CA was annually plowed to about $30-\mathrm{cm}$ depth, subject to periodical liming, and received both organic manure and mineral fertilization. This different long-term land use led to the development of two distinct phenoforms with typical soil characteristics, extensively described by Fernandez et al. (2007). Both soils were located along a small car track, partially asphalted in front of the PP soil, but hardened with mineral gravel-textured material, including industrial waste near the CA soil (Fig. 1b).

\subsection{Sampling}

Detailed soil description according to FAO (2006), prior to soil sampling was performed in a $1 \times 1 \mathrm{~m}, 1-\mathrm{m}$ deep soil pit, dug in each parcel. A first set of bulk samples was collected according to a systematic $5 \mathrm{~cm}$ depth increment from the topsoil down to at least $1-\mathrm{m}$ depth. For the annually plowed and homogenized Ap horizon of the CA soil, three samples were taken between 0 and $30 \mathrm{~cm}$. Another set was sampled to obtain bulk material, characteristic of each horizon within the profiles: A11, A12, AB, AC(g), and Cg2 for the PP soil, and Ap, Bw1, Bw2, Cg1, and Cg2 for the CA soil (Table 1). Additional surface sampling $(0-30 \mathrm{~cm})$ was performed within the two studied agricultural plots, at variable distance from the road (Fig. 1b), as well as directly in the unpaved car track. Additionally, slag samples corresponding to the different periods of former industrial activity (Thiry et al., 2002) were provided by the École des Mines at Fontainebleau (France). All samples were quartered. Representative sub-samples were air-dried, ground entirely to $<200 \mu \mathrm{m}$, and stored in closed plastic boxes prior to chemical analyses.

\subsection{Analyses}

\subsubsection{Total element concentrations}

Sub-samples of about $500 \mathrm{mg}$ were totally dissolved with $3 \mathrm{~mL} \mathrm{HF}$ and $9 \mathrm{~mL}$ of $\mathrm{HNO}_{3}$ of suprapure grade (Merck, Germany) in pressured Teflon bombs using a microwave (CEM MarsX) with settings: $15 \mathrm{~min}\left(1200 \mathrm{~W}, 2.41 \mathrm{MPa}, 170{ }^{\circ} \mathrm{C}\right)$, and $5 \mathrm{~min}$ $\left(1200 \mathrm{~W}, 2.41 \mathrm{MPa}, 180^{\circ} \mathrm{C}\right)$. The solutions were evaporated to dryness, retaken in $\mathrm{HNO}_{3}$ and then diluted with $50 \mathrm{~mL}$ of MilliQ water. Concentrations of $\mathrm{Pb}$, La, and Th were determined by inductively coupled plasma - mass spectrometry (ICP-MS) with an ELAN 5000 (Sciex/Perkin-Elmer), using both internal and external calibrations. Blanks were systematically checked and were always found low with respect to the total amount of elements in soils $(<2 \%$ for $\mathrm{Pb},<0.5 \%$ for $\mathrm{La}$, and $<0.05 \%$ for $\mathrm{Th}$ ), so that blank corrections were never required. Detection limits, expressed as concentration in bulk samples, were approximately $0.1 \mathrm{mg} \mathrm{Pb} \mathrm{kg}^{-1}, 0.2 \mathrm{mg} \mathrm{La} \mathrm{kg}{ }^{-1}$

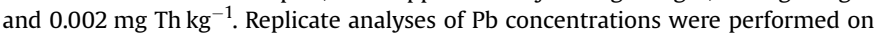
a certified reference soil sample (CRM 7001, CMI, Prague, Czech Republic) and yielded a recovery between 90 and $102 \%$ with respect to the certified values $\left(43.8 \pm 3.7 \mathrm{mg} \mathrm{kg}^{-1}\right)$. No such certified or information data were available for Th and La. Moreover, Pb concentrations of some samples of the PP soil were also measured after tri-acid digestion $\left(\mathrm{HF}, \mathrm{HClO}_{4}, \mathrm{HNO}_{3}\right)$ at INRA's National Soil Analyses Laboratory according to standardized NF X 31-147 procedures (AFNOR, 1996). The results

mog

000000

ํํำ

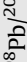

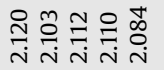

들ำ

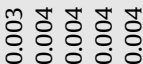

目

$+$

ह

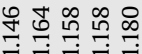

$\Xi \underset{ }{\exists} \underset{ }{\exists} \stackrel{乛}{=}$

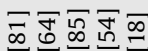

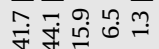

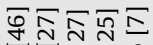

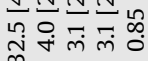

ํํㅇํำ

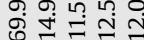

in 0 .

今ิ

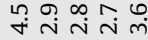

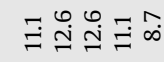

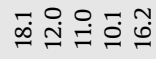

T)

$\cong \approx \bar{m}$

음ำ

ํํำ 그ํ

จิ

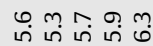

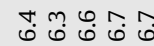

ํㅗㅇㅇํㅇ $=\infty, 1$,

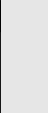

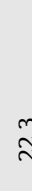

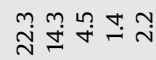


Table 2

Concentrations of $\mathrm{Th}, \mathrm{La}, \mathrm{Pb}$ and lead isotopic composition in soil samples under permanent pasture (PP) and conventional arable (CA) land

\begin{tabular}{|c|c|c|c|c|c|c|c|}
\hline $\begin{array}{l}\text { Sample } \\
\text { depth }(\mathrm{cm})\end{array}$ & $\begin{array}{l}\text { Th } \\
\left(\mathrm{mg} \mathrm{kg}^{-1}\right)\end{array}$ & $\begin{array}{l}\mathrm{La} \\
\left(\mathrm{mg} \mathrm{kg}^{-1}\right)\end{array}$ & $\begin{array}{l}\mathrm{Pb} \\
\left(\mathrm{mg} \mathrm{kg}^{-1}\right)\end{array}$ & $\begin{array}{l}{ }^{206} \mathrm{~Pb} / \\
{ }^{207} \mathrm{~Pb}\end{array}$ & \pm & $\begin{array}{l}{ }^{208} \mathrm{~Pb} / \\
{ }^{206} \mathrm{~Pb}\end{array}$ & \pm \\
\hline \multicolumn{8}{|l|}{ PP soil } \\
\hline $0-5$ & 3.1 & 11.6 & 51.6 & 1.148 & 0.004 & 2.111 & 0.010 \\
\hline $0-5$ bis $^{a}$ & & & & 1.150 & 0.003 & 2.103 & 0.003 \\
\hline $5-10$ & 3.7 & 13.0 & 64.9 & 1.150 & 0.005 & 2.107 & 0.010 \\
\hline $10-15$ & 4.6 & 15.2 & 72.6 & 1.148 & 0.004 & 2.115 & 0.009 \\
\hline $15-20$ & 4.3 & 16.2 & $62.7[55.6]$ & 1.149 & 0.004 & 2.104 & 0.009 \\
\hline $20-25$ & 3.4 & 12.5 & 43.2 & 1.147 & 0.004 & 2.113 & 0.009 \\
\hline $25-30$ & 3.6 & 14.9 & 31.2 [31.7] & 1.156 & 0.004 & 2.098 & 0.009 \\
\hline $30-35$ & 3.5 & 15.1 & $18.7[20.5]$ & 1.165 & 0.004 & 2.084 & 0.009 \\
\hline $35-40$ & 3.6 & 14.9 & 23.0 & 1.160 & 0.003 & 2.088 & 0.007 \\
\hline $40-45$ & 4.0 & 15.6 & 18.4 & 1.170 & 0.004 & 2.083 & 0.009 \\
\hline $55-60$ & 2.7 & 10.6 & 8.0 & 1.189 & 0.004 & 2.067 & 0.009 \\
\hline $60-65$ & 2.6 & 10.3 & 8.5 & 1.185 & 0.004 & 2.064 & 0.009 \\
\hline $65-70$ & 2.1 & 9.1 & 7.1 & 1.187 & 0.004 & 2.065 & 0.009 \\
\hline $70-75$ & 1.8 & 7.8 & 6.5 & 1.193 & 0.004 & 2.061 & 0.009 \\
\hline $75-80$ & 2.0 & 8.4 & $6.2[7.5]$ & 1.188 & 0.004 & 2.068 & 0.009 \\
\hline $80-85$ & 2.1 & 7.8 & 6.1 & 1.193 & 0.005 & 2.063 & 0.009 \\
\hline $85-90$ & 2.1 & 8.5 & 5.6 & 1.191 & 0.005 & 2.070 & 0.009 \\
\hline 90-95 & 2.4 & 7.1 & 5.8 & 1.189 & 0.005 & 2.061 & 0.010 \\
\hline $95-100$ & 3.0 & 8.2 & $5.6[6.4]$ & 1.191 & 0.005 & 2.063 & 0.010 \\
\hline \multicolumn{8}{|l|}{ CA soil } \\
\hline $0-10$ & 7.6 & 15.8 & 67.3 & 1.116 & 0.005 & 2.146 & 0.012 \\
\hline $0-10$ bis $^{\mathrm{a}}$ & & & & 1.120 & 0.004 & 2.146 & 0.002 \\
\hline $10-20$ & 6.6 & 13.4 & 67.4 & 1.121 & 0.005 & 2.148 & 0.012 \\
\hline $20-30$ & 6.2 & 12.5 & 71.8 & 1.117 & 0.005 & 2.155 & 0.012 \\
\hline $30-35$ & 6.7 & 15.1 & 25.9 & 1.139 & 0.005 & 2.128 & 0.012 \\
\hline $35-40$ & 8.1 & 17.3 & 19.0 & 1.148 & 0.005 & 2.115 & 0.011 \\
\hline $40-45$ & 6.0 & 12.1 & 14.8 & 1.156 & 0.005 & 2.105 & 0.012 \\
\hline $45-50$ & 5.8 & 11.0 & 11.2 & 1.176 & 0.004 & 2.084 & 0.008 \\
\hline $50-55$ & 5.9 & 11.1 & 9.6 & 1.188 & 0.003 & 2.072 & 0.007 \\
\hline $55-60$ & 5.7 & 10.6 & 9.2 & 1.192 & 0.004 & 2.064 & 0.008 \\
\hline $60-65$ & 6.5 & 11.9 & 9.2 & 1.203 & 0.004 & 2.061 & 0.008 \\
\hline $65-70$ & 6.9 & 12.8 & 9.5 & 1.207 & 0.004 & 2.055 & 0.007 \\
\hline $70-75$ & 5.3 & 11.3 & 8.1 & 1.202 & 0.004 & 2.060 & 0.008 \\
\hline $75-80$ & 7.2 & 15.4 & 10.2 & 1.202 & 0.004 & 2.058 & 0.008 \\
\hline $80-85$ & 4.7 & 10.4 & 7.5 & 1.198 & 0.004 & 2.058 & 0.009 \\
\hline $85-90$ & 6.2 & 13.7 & 8.9 & 1.198 & 0.004 & 2.063 & 0.009 \\
\hline 90-95 & 4.5 & 9.1 & 7.1 & 1.199 & 0.004 & 2.065 & 0.009 \\
\hline $95-100$ & 4.2 & 10.2 & 8.3 & 1.203 & 0.005 & 2.064 & 0.011 \\
\hline $100-105$ & 4.2 & 11.5 & 9.5 & 1.191 & 0.005 & 2.081 & 0.011 \\
\hline $105-110$ & 10.5 & 22.2 & 12.9 & 1.198 & 0.005 & 2.075 & 0.012 \\
\hline
\end{tabular}

Between brackets: lead concentration measured at the INRA's National Analyses Laboratory (see text for details).

a Lead isotopic compositions measured by MC-ICP-MS at the University of Montpellier II.

(Table 2, data between brackets) indicate good reproducibility of $\mathrm{Pb}$ concentrations obtained with independent determinations.

\subsubsection{EDTA extractions}

Lead extractability was measured on sub-samples from all horizons samples, after $24 \mathrm{~h}$ contact with a $0.05 \mathrm{M}$ ethylene diamine tetraacetic acid (EDTA) extraction reagent using a soil/solution ratio of $1: 10$. Since many of the reactions with the extracting agents were $\mathrm{pH}$ dependent, all extracting solutions used in this work had a $\mathrm{pH}$ adjusted to 6.6 by adding adapted amounts of $\mathrm{NaOH}$ (Ghestem and Bermond, 1998; Labanowski et al., 2008). Work of Fangueiro et al. (2002) showed that a pH of about 6 guaranteed minimal variations of $\mathrm{pH}$ during extraction and hence, prevented competitive extraction by $\mathrm{H}^{+}$. Extraction solutions were filtered through a $0.45-\mu \mathrm{m}$ cellulose acetate membrane (Millipore) and $\mathrm{Pb}$ concentration in the extracts was measured by ICP-MS, as described above.

\subsubsection{Isotopic composition measurements}

Lead isotopic compositions were measured using a quadrupole-based ICP-MS at the University of Toulouse (France). For some samples, duplicate measurements were run on a HP 4500 at the University of Geneva (Switzerland), and on a VG PQ2 at the University of Montpellier II (France). Mass bias was corrected by bracketing a NIST 981 isotopic lead standard. Further details about the complete procedure can be found elsewhere (Monna et al., 1998, 2000). Duplicates (noted 'bis', Tables 2 and 3) showed reproducibility within the limits of the instrumental error (approximately $0.4-0.5 \%$, at a $95 \%$ confidence level, for the ${ }^{206} \mathrm{~Pb} /{ }^{207} \mathrm{~Pb}$ and ${ }^{208} \mathrm{~Pb} /{ }^{206} \mathrm{~Pb}$ ratios, respectively).

\section{Table 3}

Total lead concentrations and isotopic compositions in samples from different locations in the permanent pasture (PP) plot, conventional arable (CA) land plot and from the unpaved car track

\begin{tabular}{lcclll}
\hline Location & $\mathrm{Pb}\left(\mathrm{mg} \mathrm{kg}^{-1}\right)$ & ${ }^{206} \mathrm{~Pb} /{ }^{207} \mathrm{~Pb}$ & \pm & ${ }^{208} \mathrm{~Pb} /{ }^{206} \mathrm{~Pb}$ & \pm \\
\hline PP plot & & & & & \\
PPa & 43 & 1.148 & 0.002 & 2.099 & 0.007 \\
PPa-bis & - & 1.151 & 0.003 & 2.109 & 0.006 \\
PPb & 46 & 1.143 & 0.003 & 2.119 & 0.004 \\
PPc & 45 & 1.146 & 0.003 & 2.119 & 0.007 \\
PP $(0-5 \mathrm{~cm})^{\mathrm{a}}$ & 52 & 1.148 & 0.004 & 2.111 & 0.010 \\
& & & & & \\
CA plot & & & & & 0.005 \\
CAa & 69 & 1.126 & 0.003 & 2.138 & 0.009 \\
CAa-bis & - & 1.125 & 0.003 & 2.131 & 0.007 \\
CAb & 59 & 1.136 & 0.004 & 2.127 & 0.004 \\
CAb-bis & - & 1.137 & 0.003 & 2.133 & 0.005 \\
CAc & 44 & 1.128 & 0.002 & 2.127 & \\
CA (0-10 cm) & 67 & 1.120 & 0.004 & 2.146 & \\
& & & & & 0.009 \\
Car track & & & & & 0.005 \\
R1 & 75 & 1.154 & 0.005 & 2.104 & 0.005 \\
R2 & 102 & 1.145 & 0.002 & 2.115 & \\
R3 & 330 & 1.151 & 0.003 & 2.111 & \\
\hline
\end{tabular}

Replicates samples of isotopic compositions are indicated as 'bis'.

a Data from the surface samples of the study soils (cf. Table 2).

\section{Results}

\subsection{Physicochemical data in the PP and CA soils}

The pedogenetic connection between the two soils was confirmed by mineralogical and micromorphological work of Fernandez et al. (2007). It is illustrated here by comparable data of CEC, texture and total iron contents (Table 1 ): rather low in the upper $70-80 \mathrm{~cm}$, but markedly increasing in the $\mathrm{Cg} 2$ horizons. The cation exchange complex was dominated by $\mathrm{Ca}^{2+}$, and base saturation reached almost $100 \%$, except for the surface horizons of $\mathrm{PP}(\sim 90 \%)$, mainly ascribed to a slightly lower $\mathrm{pH}$. Lower concentrations of organic carbon in CA compared to the PP soil were found typical for organic matter dynamics in cultivated and permanent grassland soils. The bulk density was clearly lower in PP (Table 1) explained by much higher biological activity in comparison to CA, where repetitive plowing of the Ap is likely to favor compaction of the underlying (B)1 horizon.

\subsection{Elemental and isotopic geochemistry}

\subsubsection{The CA and PP profiles}

Lead concentration profiles obtained on bulk samples from both soils showed a clear decrease below the A horizons, although some marked differences were noted (Table 1; Fig. 2a, b). The Ap horizon of the CA soil (Fig. 2b) showed high and rather homogeneous $\mathrm{Pb}$ concentrations (65-70 $\mathrm{mg} \mathrm{kg}^{-1}$ ), rapidly decreasing below, reaching about $14 \mathrm{mg} \mathrm{kg}^{-1}$ at the basis of (B) 1 and less than $10 \mathrm{mg} \mathrm{kg}^{-1}$ at greater depth. In the PP soil (Fig. 2a), Pb contents peaked in the A12 horizon and decreased progressively to about $15 \mathrm{mg} \mathrm{kg}^{-1}$ at $40-45 \mathrm{~cm}$ and about $6 \mathrm{mg} \mathrm{kg}^{-1}$ at $95-100-\mathrm{cm}$ depth $(\mathrm{Cg} 2)$. The decrease of $\mathrm{Pb}$ concentrations toward depth was more progressive for the PP than for the CA soil. Comparable patterns were obtained with EDTA extraction data, depicted by dotted lines in Fig. 2a and b. The proportions of total lead extracted by EDTA were, however, higher in the A and B horizons of the PP soil (54-85\%) than at comparable depth in the CA soil (25-46\%). Lanthanum contents in bulk samples were roughly constant all along the CA profile (10$15 \mathrm{mg} \mathrm{kg}^{-1}$ ), whereas in the PP soil, they decreased between the upper $50 \mathrm{~cm}\left(12-15 \mathrm{mg} \mathrm{kg}^{-1}\right)$ and deeper $\mathrm{AC}(\mathrm{g})$ and $\mathrm{Cg} 2$ horizons 

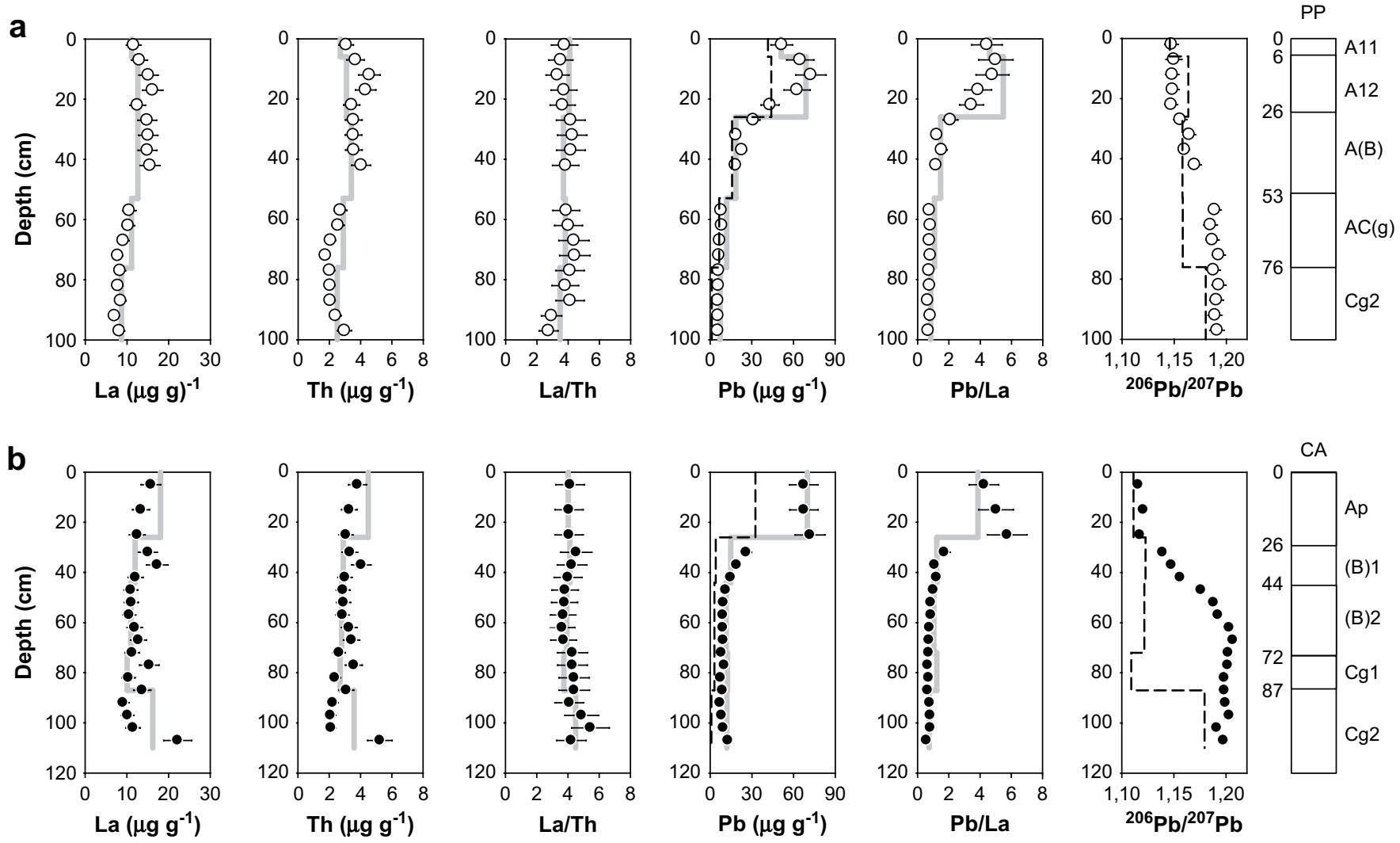

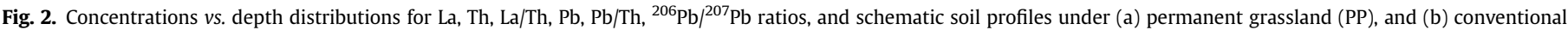

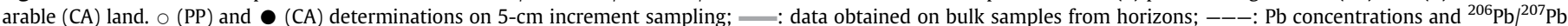
ratios measured on 24-h EDTA extractions.

(7-10 $\left.\mathrm{mg} \mathrm{kg}^{-1}\right)$. Thorium concentration profiles showed similar trends compared to lanthanum, so that $\mathrm{La} / \mathrm{Th}$ ratios were quite stable with depth. The observed ratio $\sim 4$ is close to the average value observed for La/Th ratios in the upper continental crust ( 3.1; Wedepohl, 1995). Results from 5 to $10-\mathrm{cm}$ increment sampling were in good agreement with those obtained on bulk horizon samples (bold gray segments in Fig. 2).

In the CA profile, lowly radiogenic ${ }^{206} \mathrm{~Pb} /{ }^{207} \mathrm{~Pb}$ ratios $(\sim 1.12)$ were found in the Ap horizon (Fig. 2b). The ${ }^{206} \mathrm{~Pb} /{ }^{207} \mathrm{~Pb}$ ratios strongly increased to about 1.20 at $60-65-\mathrm{cm}$ depth and remained steady until 1-m depth. Values around 1.20 are in the range (1.181.22) of those frequently reported for $\mathrm{Pb}$ naturally present in rocks and soils of Western Europe (Monna et al., 1998; Lévêque et al., 2002; Semlali et al., 2001, 2004; Sterckeman et al., 2006b). In the PP profile, ${ }^{206} \mathrm{~Pb} /{ }^{207} \mathrm{~Pb}$ ratios were found between 1.145 and 1.150 in the first $25 \mathrm{~cm}$, between 1.15 and 1.16 in the $A(B)$ horizon until about 50-cm depth, and between 1.18 and 1.19 until 1-m soil depth (Fig. 2a). Hence, the observed variation of ${ }^{206} \mathrm{~Pb} /{ }^{207} \mathrm{~Pb}$ ratios was much greater in CA (1.116-1.207) than in PP (1.148-1.193). In $a^{208} \mathrm{~Pb} /{ }^{206} \mathrm{~Pb} v$ s. ${ }^{206} \mathrm{~Pb} /{ }^{207} \mathrm{~Pb}$ diagram, all samples plotted along one single line (Fig. 3) suggests either a multi-component mixing with two Pb sources, or more than two sources which would be in collinear position. Yet, the ${ }^{208} \mathrm{~Pb} /{ }^{206} \mathrm{~Pb}$ data of the $\mathrm{CA}$ were higher than those observed for the PP soil, suggesting different contaminating $\mathrm{Pb}$ sources between the two soils.

The ${ }^{206} \mathrm{~Pb} /{ }^{207} \mathrm{~Pb}$ ratios measured in EDTA extracts, represented by dotted lines in Fig. 2 were about 1.11-1.13 for CA and 1.14-1.16 for $\mathrm{PP}$ in all samples at $<80-\mathrm{cm}$ depth. At greater depth, the ${ }^{206} \mathrm{~Pb} /{ }^{207} \mathrm{~Pb}$ ratios increased markedly in both soils. Except for the A12 horizon of PP, the EDTA extracts were always less radiogenic than the corresponding bulk samples.

\subsubsection{Surface samples and metallurgical waste}

Three replicates of surface samples $(0-30 \mathrm{~cm})$ collected at different locations in the PP plot provided rather homogeneous $\mathrm{Pb}$ concentrations and ${ }^{206} \mathrm{~Pb} /{ }^{207} \mathrm{~Pb}$ ratios: $43-46 \mathrm{mg} \mathrm{kg}^{-1}, 1.143-1.148$, respectively (Fig. 1b, Table 3 ). Higher variability was recorded

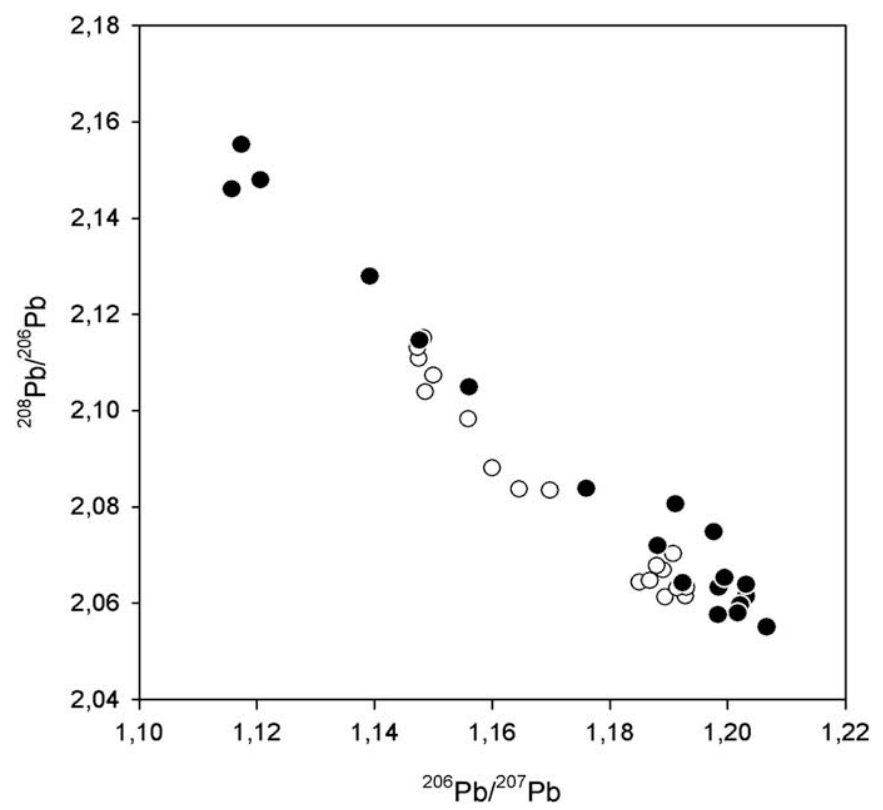

Fig. 3. ${ }^{208} \mathrm{~Pb} /{ }^{206} \mathrm{~Pb}$ vs. ${ }^{206} \mathrm{~Pb} /{ }^{207} \mathrm{~Pb}$ ratios diagram established for $5-10 \mathrm{~cm}$ increment sampling to 1-m depth for the PP soil $(O)$ and the CA soil $(\mathbf{0})$ 
within the $\mathrm{CA}$ plot: $\mathrm{Pb}$ concentrations ranged from 44 to $69 \mathrm{mg} \mathrm{kg}^{-1}$ and ${ }^{206} \mathrm{~Pb} /{ }^{207} \mathrm{~Pb}$ ratios from 1.126 to 1.136 . These values are coherent with the $\mathrm{Pb}$ concentrations and isotopic compositions measured in the topsoil samples of the studied profiles (Fig. 1b). In order to explain these differences between PP and CA, the possible influence of the unpaved track in front of the CA plot was checked by analyzing three road samples (Fig. $1 \mathrm{~b}$, Table 3 ). Although the $\mathrm{Pb}$ concentrations varied from 75 to $330 \mathrm{mg} \mathrm{kg}{ }^{-1}$, the ${ }^{206} \mathrm{~Pb} /{ }^{207} \mathrm{~Pb}$ ratios were rather similar (1.145-1.154). Additional analyses of different samples of metallurgical waste, collected at different locations of the former industrial site, displayed huge variations, both with respect to total $\mathrm{Pb}$ contents as well as $\mathrm{Pb}$ isotopic compositions (Table 4).

\section{Discussion}

\subsection{Data preparation and calculation of anthropogenic lead pools in soil profiles}

A major problem when studying lead migration in soils is to distinguish discrete anthropogenic lead contributions in deep soil layers, where endogenic lead from the natural background represents the dominant lead pool. At depth, contributions of endogenic $\mathrm{Pb}$ may significantly vary over short distances due to changes in mineralogical composition. Such variation may be palliated by performing normalization with respect to a conservative element with no anthropogenic origin, such as Sc, Th, Zr, or a rare earth element. This proceeding is frequently applied in environmental geochemistry. In unpolluted soil horizons, metals and conservative trace elements may vary in magnitude, but a rationing operation is supposed to provide quasi-constant values. Consequently, notable increase from the rationed background values points out the presence of anthropogenic components. Both studied soils present appreciable and concomitant La and Th content changes. Since La/ Th ratios are stable along the profile, these two elements likely have a common natural origin, and their distributions with depth are ascribed to mineralogical variations (Fig. 2, Table 1). As a result endogenic $\mathrm{Pb}$ is expected to vary proportionally. The trends of $\mathrm{Pb} / \mathrm{La}$ and total $\mathrm{Pb}$ profiles are approximately the same for both soils (Fig. 2a, b). However, small variations of $\mathrm{Pb}$ concentrations in the $\mathrm{C}$ horizons of the CA soil are eliminated in the $\mathrm{Pb} / \mathrm{La}$ profile due to the rationing operation. The values of $\mathrm{Pb} / \mathrm{La}$ ratios are similar in $\mathrm{C}$ horizons for both soils: $\sim 0.7-0.8$, but ${ }^{206} \mathrm{~Pb} /{ }^{207} \mathrm{~Pb}$ ratios slightly differ: $\sim 1.18-1.19$ for PP and $\sim 1.20$ for CA. The more radiogenic values likely correspond to the lowest contributions of anthropogenic lead. However, the deepest horizons of CA may not fully represent the real background conditions since isotopic compositions of the EDTA extractions in the Cg2 horizon $\left({ }^{206} \mathrm{~Pb} /{ }^{207} \mathrm{~Pb} \sim 1.18\right.$, Table 1) suggest minor but noticeable incorporation of anthropogenic lead.

\begin{tabular}{|c|c|c|c|}
\hline $\begin{array}{l}\text { Industrial } \\
\text { waste samples }^{\mathrm{a}}\end{array}$ & $\begin{array}{l}\mathrm{Pb}^{\mathrm{a}} \\
\left(\mathrm{mg} \mathrm{kg}^{-1}\right)\end{array}$ & ${ }^{206} \mathrm{~Pb} /{ }^{207} \mathrm{~Pb}$ & Sample characteristics ${ }^{\mathrm{a}}$ \\
\hline IW-1007 & 677 & 1.125 & $\begin{array}{l}\text { Black, loose industrial scoriae; no sulfides; } \\
40 \mathrm{~cm} \text { depth }\end{array}$ \\
\hline IW-1056 & 743 & 1.137 & $\begin{array}{l}\text { Dark scoriae and slag; no sulfides; } \\
0-200 \mathrm{~cm} \text { depth }\end{array}$ \\
\hline IW-1056X & 750 & 1.148 & $\begin{array}{l}\text { Reddish oxidized scoriae; no sulfides; } \\
75 \mathrm{~cm} \text { depth }\end{array}$ \\
\hline IW-1216 & $\sim 10,000$ & 1.296 & $\begin{array}{l}\text { Cemented, reddish-orange scoriae; } \\
\text { sulfides; 220 cm depth }\end{array}$ \\
\hline IW-1217 & $\sim 20,000$ & 1.140 & $\begin{array}{l}\text { Scoriae, slag and crucible fragments; } \\
\text { sulfides; } 0-30 \mathrm{~cm} \text { depth }\end{array}$ \\
\hline
\end{tabular}

\footnotetext{
a Numbers and descriptions from Thiry et al. (2002).
}

This may explain a slightly lower estimation of ${ }^{206} \mathrm{~Pb} /{ }^{207} \mathrm{~Pb}$ ratio for the background values in our work $(\sim 1.20)$ in comparison to the data reported ( $\sim 1.21-1.22)$ by Sterckeman et al. (2006b) for soils developed in loess formations in northern France.

In a first approximation, it seems reasonable to assess roughly the background from these $\mathrm{C}$ horizons, with: $\mathrm{Pb} / \mathrm{La}=0.73 \pm 0.06$ and ${ }^{206} \mathrm{~Pb} /{ }^{207} \mathrm{~Pb}=1.200 \pm 0.004$ (at a 95\% confidence level). The anthropogenic part contributing to the total lead concentration, $\mathrm{Pb}_{\text {Anthr, }}$ can be computed for each layer of the two soils (Shotyk et al., 2000; Semlali et al., 2001):

$\mathrm{Pb}_{\text {Anthr. }}=\mathrm{Pb}_{m}-\mathrm{La}_{m} \times\left(\frac{\mathrm{Pb}}{\mathrm{La}}\right)_{\text {Back. }}$,

where $\mathrm{La}_{m}$ and $\mathrm{Pb}_{m}$ represent the $\mathrm{La}$ and $\mathrm{Pb}$ concentrations of each sample, and $(\mathrm{Pb} / \mathrm{La})_{\text {Back. }}$ the assessed ratio of the background (see above). Then, the anthropogenic pool $\mathrm{Pb}_{\mathrm{Anthr}}$, expressed per surface unit, is obtained by:

$\mathrm{Pb}_{\text {Anthr. }}=\sum_{i=1}^{n}\left[\left(\mathrm{~Pb}_{\text {Anthr. }}\right)_{i} \times e_{i} \times d_{i}\right]$,

where $\left(\mathrm{Pb}_{\text {Anthr. }}\right)_{i}, e_{i}$ and $d_{i}$ are the anthropogenic contribution to the total lead concentration in the horizon $i$, its thickness and bulk density, respectively. Calculations performed to 1-m soil depth yielded anthropogenic lead pools per surface unit at about $28 \pm 4 \mathrm{~g} \mathrm{~m}^{-2}$ for the CA soil and $21 \pm 4 \mathrm{~g} \mathrm{~m}^{-2}$ for the PP soil. These values are clearly higher than those mentioned by Sterckeman et al. (2006a) for other soils of northern France (3.6 $\mathrm{g} \mathrm{m}^{-2}$ ), for soils from a Swiss National Park $\left(2.2 \mathrm{~g} \mathrm{~m}^{-2}\right)$ or for soils exposed to city pollution $\left(\sim 16 \mathrm{~g} \mathrm{~m}^{-2}\right)$, the latter data being reported by Hansmann and Köppel (2000).

\subsection{Anthropogenic lead dynamics in soils}

Distinct land use lasting for 100 years produced two soil phenoforms mainly differing in incorporation of organic matter and soil aggregation, ascribed partly to a different vegetation and rooting, but more particularly to a clear different earthworm activity (Fernandez et al., 2007). Hence, incorporation of anthropogenic lead in soils appeared to be driven to a large extent by bioturbation. Large differences in earthworm activity have been previously demonstrated for these two soils: $392 \pm 12$ earthworms $\mathrm{m}^{-2}$ in PP and $52 \pm 5$ earthworms $\mathrm{m}^{-2}$ in CA (Nahmani et al., 2003). In addition, in the PP soil, a significant higher amount of endogenic worms moving to $>80-\mathrm{cm}$ depth were observed. In the CA soil, mainly epigenic species occurred with an activity restricted mostly to the plow layer. These different effects of biological activity were corroborated by micromorphological study on soil thin sections showing different characteristic organomineral micro-structures (Fernandez et al., 2007). Although the $\mathrm{pH}$ in the surface horizons of the PP soil (5.3-5.6) is about one unit lower than in the CA soil (6.3-6.4), the soil under permanent grassland contains a clear higher amount of organic carbon $\left(5.7 \mathrm{~kg} \mathrm{~m}^{-2}\right.$ in PP vs. $3.5 \mathrm{~kg} \mathrm{~m}^{-2}$ in CA, for the upper $26 \mathrm{~cm}$, cf. Table 1), favoring $\mathrm{Pb}$ immobilization (Kuo and Harsh, 1997). The main Pb-migration mechanism in the PP soil is therefore attributed to a biomechanical movement of fine, metal-contaminated soil particles via earthworms. This hypothesis is corroborated by the work of Sterckeman et al. (2000) who compared the content of trace metals in earthworm galleries and the bulk horizon in which the galleries occurred, until $95 \mathrm{~cm}$ soil depth. They showed that the ground mass contaminated with metals in the galleries was coming from the surface horizons. This explains why anthropogenic lead was identified as deep as the Cg2 horizon in the PP soil. In the CA soil, most of the $\mathrm{Pb}$ is immobilized in the Ap horizon (Fig. 2a) due to 
fertilizing and liming applications. Its distribution is homogeneous in the first $30 \mathrm{~cm}$ because of annual plowing. At lower depths, because of low earthworm activity, the amount of anthropogenic $\mathrm{Pb}$ rapidly decreases. Yet, minor $\mathrm{Pb}$ transfer in colloidal form and its precipitation at depth due to changing redox conditions as suggested by Citeau et al. (2003) and van Oort et al. (2006) cannot be ruled out.

\subsection{Characterizing anthropogenic lead}

Different kinds of anthropogenic $\mathrm{Pb}$ with varying isotopic characteristics have been deposited in variable amounts at the surface of the soils over time. They represent today the overall anthropogenic pool which has been redistributed in different horizons according to land use and specific soil behavior. It is obviously impossible, on the sole basis of parameters measured in the present study, to identify and to apportion precisely the different components of such a complex mixture. Nonetheless, the average isotopic composition of the anthropogenic $\mathrm{Pb}$ pool might be theoretically calculated for each horizon by using classical mixing model equations that consider $\mathrm{Pb}$ concentrations and isotopic compositions. Fundamentals can be found in Faure (1986), and Hansmann and Köppel (2000) for specific application in soils. In such a model, lead isotopic compositions and lead concentrations of the background are assumed to be reasonably constant.

Using a ${ }^{206} \mathrm{~Pb} /{ }^{207} \mathrm{~Pb}$ vs. $1 / \mathrm{Pb}$ diagrams (Fig. 4a), the average isotopic composition of the (pure) pollutant can be inferred by examining the intercept on the ${ }^{206} \mathrm{~Pb} /{ }^{207} \mathrm{~Pb}$ axis of a straight line linking the background to any contaminated sample. In our study, both soil profiles develop lines defining an approximate isotopic composition of the anthropogenic pool of the surface horizons: 1.10-1.11 for CA and 1.14-1.15 for PP, respectively. However, two distinct soil backgrounds have to be invoked (cf. Fig. 4a), which are unlikely because of the geographical proximity and the pedogenetic connection of the two soils. The usefulness of ${ }^{206} \mathrm{~Pb} /{ }^{207} \mathrm{~Pb}$ vs. $\mathrm{La} / \mathrm{Pb}, \mathrm{Sc} / \mathrm{Pb}$ or $\mathrm{Al} / \mathrm{Pb}$ diagrams instead of the more commonly used ${ }^{206} \mathrm{~Pb} /{ }^{207} \mathrm{~Pb}$ vs. $1 / \mathrm{Pb}$ diagram, has already been highlighted in different studies dealing with peat bogs (Monna et al., 2004), soils (Semlali et al., 2001), and lichens (Spiro et al., 2004; Monna et al., 2006). With $\mathrm{La} / \mathrm{Pb}$ or $\mathrm{Th} / \mathrm{Pb}$ ratios used as X-axis (Fig. $4 \mathrm{~b}, \mathrm{c}$ ), the deepest samples of CA probably still not fully reach the background, but they appear in upper right position in the diagram, indicating that they are less influenced by anthropogenic component than PP samples, collected at comparable depth. Although not formally characterized, the plausible position of the background indicated in Fig. 4 as a gray box, appears now compatible with both soil profiles.

Even if normalization with $\mathrm{La} / \mathrm{Pb}$ or $\mathrm{Th} / \mathrm{Pb}$ ratios provides a much clearer view by providing a single background for both soils, the estimations concerning the average ${ }^{206} \mathrm{~Pb} /{ }^{207} \mathrm{~Pb}$ ratio of anthropogenic lead contaminating the upper $45 \mathrm{~cm}$ of the PP and $\mathrm{CA}$ are not drastically affected by the use of $\mathrm{La} / \mathrm{Pb}$ or $\mathrm{Th} / \mathrm{Pb}$ ratios instead of the $1 / \mathrm{Pb}$ ratio: they remain around about 1.14 and 1.10 , respectively. Lead contamination rates in these horizons are sufficiently high so that calculations are little sensitive to minor errors in background correction. By contrast, for depths $>45 \mathrm{~cm}$, average isotopic composition of the anthropogenic pool cannot be properly assessed because constraining the line linking the supposed background to lowly contaminated samples becomes difficult or impossible. Here, results of EDTA extractions can help to check the pertinence of the assessment of the anthropogenic pool. The ${ }^{206} \mathrm{~Pb} /{ }^{207} \mathrm{~Pb}$ ratios of EDTA extracts within the first $50 \mathrm{~cm}$ of the PP and CA profiles are about $1.14-1.16$ and $1.11-1.12$, respectively (Table 1 ), i.e. values comparable though slightly more radiogenic than assessments based on ${ }^{206} \mathrm{~Pb} /{ }^{207} \mathrm{~Pb} v$ s. La/Pb and $\mathrm{Th} / \mathrm{Pb}$ ratios. Although EDTA extractions were mentioned to predominantly remove anthropogenic lead (Komárek et al., 2006), this method is not purely selective as both natural and more radiogenic lead may also be extracted, depending on its speciation in the soil.

Yet, our results indicate that these two neighboring soils either did not integrate the same anthropogenic lead, or that two or more sources were involved but in unequal proportions. This surprising finding is not an artifact due to the treatment procedure which combines $\mathrm{La} / \mathrm{Pb}$ and ${ }^{206} \mathrm{~Pb} /{ }^{207} \mathrm{~Pb}$ ratios since independent analyses by EDTA extractions provide comparable results. Hence, considering the geographical proximity of the two soils, it may be obvious that they received similarly the $\mathrm{Pb}$ inputs due to metallurgical fallout, and more generally by remote industrial/automotive emissions. The ${ }^{206} \mathrm{~Pb} /{ }^{207} \mathrm{~Pb}$ ratios of metallurgical wastes vary greatly: 1.125-1.296 (Table 4), underlining the large variety of metal-ores treated during the 60-year activity. In such a situation, the potentiality of the lead isotope approach for source apportioning (and even for source recognition) is severely compromised. It is, however, tempting to explain the isotopic differences observed in topsoil samples from CA and PP plots by local influences.
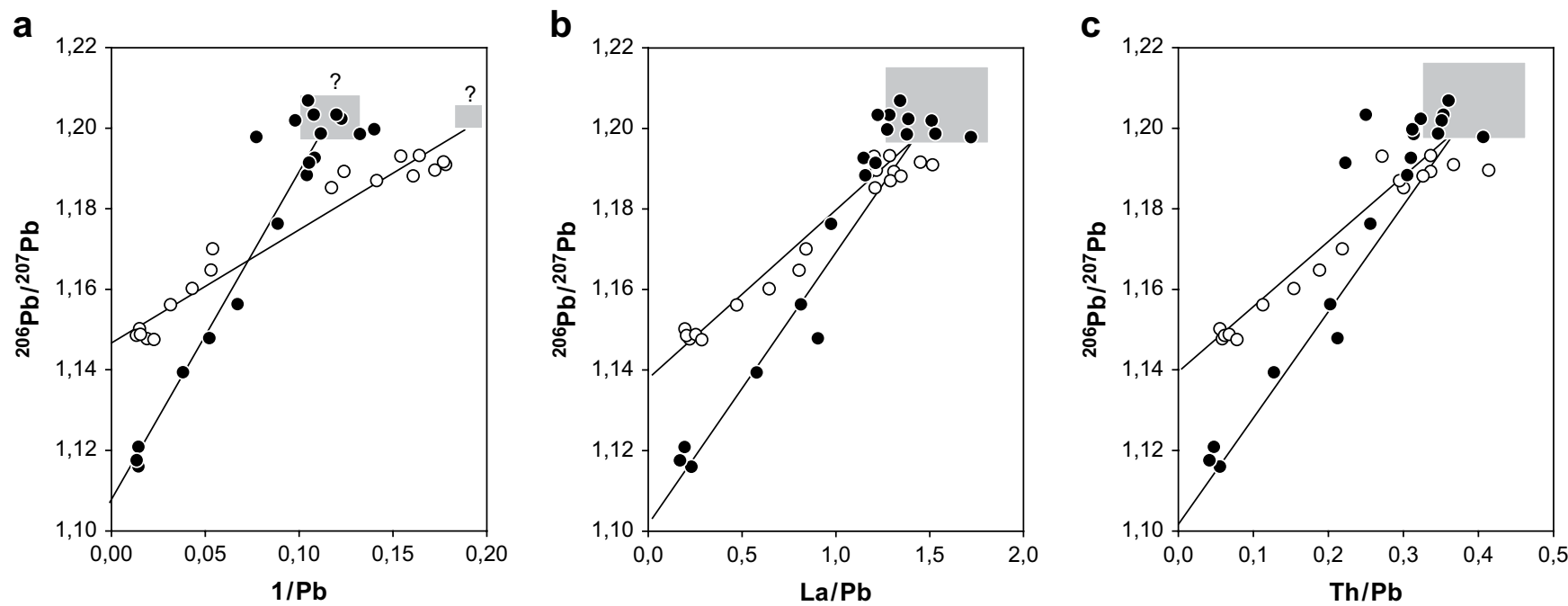

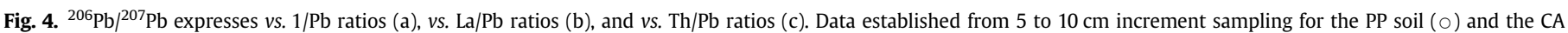
soil (@). 
1. The proximity of a road track embanked with contaminated smelter waste may produce periodically metalliferous dust contaminating surrounding soils. With respect to this potential lead source, the CA plot is located windward of the road, contrarily to the PP plot. Moreover, in front of the PP plot the road is tarred. Consequently, both plots are not subject similarly to contaminated road dust. Different replicates of surface samples of the $\mathrm{CA}$ plot suggested $\mathrm{Pb}$ contamination, decreasing from about 60 to $70 \mathrm{mg} \mathrm{kg}^{-1}$ close to the road to about $45 \mathrm{mg} \mathrm{kg}^{-1}$ at $100 \mathrm{~m}$ away (Fig. 1 b, Table 3 ). But $l o{ }^{206} \mathrm{~Pb} /{ }^{207} \mathrm{~Pb}$ ratios (1.1201.136) observed for CA surface samples are incompatible with significant contamination by road dust regarding the isotopic signatures of the car track samples (1.145-1.154). Contamination of the PP plot by road dust is unlikely due to its leeward position to the road and no $\mathrm{Pb}$ content gradient is observed. Consequently, other explanations must be examined.

2. Lead antiknock compounds used from the late 1970s to the 1990s in Western Europe are known to have been lowly radiogenic $\left({ }^{206} \mathrm{~Pb} /{ }^{207} \mathrm{~Pb}\right.$ ratios $\sim 1.06-1.10$, Elbaz-Poulichet et al., 1984, 1986; Monna et al., 1998). They might be involved in the anthropogenic lead pool of the first $50 \mathrm{~cm}$ of the CA soil. But, diffuse lead contamination deriving from car traffic would have affected similarly both agricultural plots. Hence, anthropogenic lead of the PP soil should be lowly radiogenic too.

3. Differences in agronomic management of arable land and permanent pasture are more likely to explain the divergent $\mathrm{Pb}$ isotopic compositions in the topsoils of the CA and PP plots. Harvesting of cultivars for more than 100 years from arable land may have exported a part of atmospherically deposited lead (originating predominantly from the factory), while fertilization and various mineral or organic (waste) amendments may have introduced an unknown but yet significant amount of lowly radiogenic lead, affecting more specifically the cultivated land. With this latter scenario, unfortunately poorly constrained, the apparent resemblance of anthropogenic lead pools (i.e. $28 \pm 4 \mathrm{~g} \mathrm{~m}^{-2}$ for CA and $21 \pm 4 \mathrm{~g} \mathrm{~m}^{-2}$ for PP) would be purely fortuitous.

\section{Conclusion}

This study demonstrated the complementarity and adequation of the $\mathrm{Pb}$ isotopic compositions, La- or Th-normalization, and EDTA extraction approaches for assessing the migration of anthropogenic lead in soils. Detailed information on soil mineralogical, micromorphological, and physicochemical characteristics, soil behavior and metal distribution patterns are nonetheless essential for a pertinent exploitation of results. In the selected paired agricultural plots, anthropogenic lead clearly moved down to 1-m depth in a soil under permanent pasture. In the soil under arable land, more anthropogenic lead was accumulated in the plow horizon, but significant movement of lead was detected to about $60-\mathrm{cm}$ depth, and some lead contamination was suspected until the $\mathrm{Cg} 2$ horizon. These different distribution patterns of anthropogenic lead were mainly ascribed to soil management and inherent biological (earthworm) activity. The $\mathrm{Pb}$ isotope approach was revealed to be a powerful tool for providing detailed insight in the incorporation dynamics of anthropogenic lead in soils under long-term different land use. Even if the origin of lead could not be determined with precision within each agricultural soil by lead isotopes, it appeared that these agricultural plots, only distant of some hundred meters, did not integrate the same anthropogenic inputs. This surprising result underlines the importance of collecting a maximum of information on historical land use and agricultural practices, since the role of human in these anthropized ecosystems is crucial and long-lasting. Consequently, an important variability at the scale of agricultural plots may arise with time regarding the origin, dissemination ways and behavior of lead is induced, even in case of such carefully selected neighboring soils with comparable pedogenesis.

\section{Acknowledgments}

The authors are grateful to Sébastien Breuil and Anne Jaulin of INRA, Versailles, for help with soil sampling and preparation, and for assistance with AAS, respectively. We thank M. Delzenne at Mortagne-du-Nord for valuable historical information on the studied agricultural plots and providing field-sampling facilities. Technical assistance at the Toulouse University, at the Montpellier University and at the Geneva University is greatly acknowledged. This work was partly financially supported by the French National Research program ToxNuc-E. Christelle Fernandez gratefully acknowledges a research allowance from the French Ministry of Research and Technology (MRT). The authors wish to thank also the two anonymous reviewers for their valuable comments and recommendations of the first draft.

\section{References}

Abollino, O., Aceto, M., Malandrino, M., Mentasti, E., Sarzanini, C., Barbaris, R., 2002. Distribution and mobility of metals in contaminated sites. Chemometric investigation of pollutant profiles. Environmental Pollution 119, 177-193.

AFNOR, 1996. Qualité des sols. Recueil de Normes Françaises. AFNOR, Paris, France. Andersen, M.K., Raulund-Rasmussen, K., Hansen, H.C.B., Strobel, W., 2002. Distribution and fractionation of heavy metals in pairs of arable and afforested soils in Denmark. European Journal of Soil Science 53, 491-502.

Bacon, J.R., Hewitt, I.J., 2005. Heavy metals deposited from the atmosphere on upland Scottish soils: chemical and lead isotope studies of the association of metals with soil components. Geochimica et Cosmochimica Acta 69, 19-33.

Blum, W.E.H., Brandstetter, A., Wenzel, W.W., 1997. Trace Element Distribution in Soil as Affected by Land Use. In: Adriano, D.C., Chen, Z.-S., Yang, S.-S., Iskandar, I.-K. (Eds.), Biogeochemistry of Trace Metals. Advances in Environmental Science. Science Reviews, Northwood, England, pp. 61-73.

Citeau, L., Lamy, I., van Oort, F., Elsass, F., 2003. Colloidal facilitated transfer of metals in soils under different land use. Colloids and Surfaces A 217, 11-19.

Elbaz-Poulichet, F., Holliger, P., Huang, W.W., Martin, J.M., 1984. Lead cycling in estuaries, illustrated by the Gironde estuary, France. Nature 308, 409-414.

Elbaz-Poulichet, F., Holliger, P., Martin, J.M., Petit, D., 1986. Stable lead isotopes ratios in major French rivers and estuaries. Science of the Total Environment 54, 61-76.

Emmanuel, S., Erel, Y., 2002. Implications from concentrations and isotopic data for $\mathrm{Pb}$ partitioning processes in soils. Geochimica et Cosmochimica Acta 66, $2517-$ 2527.

Erel, Y., Patterson, C.C., Scott, M.J., Morgan, J.J., 1990. Transport of industrial lead snow through soil to stream water and groundwater. Chemical Geology 85 383-392.

Ettler, V., Milhaljevič, M., Komárek, M., 2004. ICP-MS measurements of lead isotopic ratios in soils heavily contaminated by lead smelting: tracing the sources of pollution. Analytical Bioanalytical Chemistry 378, 311-317.

Fangueiro, D., Bermond, A., Santos, E., Carapuca, H., Duarte, A., 2002. Heavy metal mobility assessment in sediments based on a kinetic approach of the EDTA extraction: search for optimal experimental conditions. Analytica Chimica Acta 459, 245-256.

FAO, 1998. World Reference Base for Soil Resources. World Soil Resources Report 38 FAO-ISRIC-ISSS, Rome, Italy.

FAO, 2006. Guidelines for Soil Profile Description, fourth ed. F.A.O., Rome, Italy.

Farmer, J.G., Graham, M.C., Bacon, J.R., Dunn, S.M., Vinagradoff, S.I., MacKenzie, A.B. 2005. Isotopic characterisation of the historical lead deposition record at Glensaugh, an organic rich, upland catchment in rural N.E. Scotland. Science of the Total Environment 346, 121-137.

Faure, G., 1986. Principles of Isotope Geology. Wiley and Sons, New York, USA.

Fernandez, C., Labanowski, J., Cambier, P., Jongmans, A.G., van Oort, F., 2007. Fate of airborne metal pollution in soils as related to agricultural management. 1. Zn and $\mathrm{Pb}$ distributions in soil profiles. European Journal of Soil Science 58, 547559.

Ghestem, J.P., Bermond, A., 1998. EDTA extractability of trace metals in polluted soils. Environmental Technology 19, 409-416.

Haack, U.K., Heinrichs, H., Gutsche, F.H., Plessow, K., 2003. The isotopic composition of anthropogenic $\mathrm{Pb}$ in soil profiles of Northern Germany: evidence for pollutant $\mathrm{Pb}$ from a continent-wide mixing system. Water, Air, and Soil Pollution $150,113-134$.

Hansmann, W., Köppel, V., 2000. Lead-isotopes as tracer of pollutants in soils. Chemical Geology 171, 123-144.

Hernandez, L., Probst, A., Probst, J.-L., Ulrich, E., 2003. Heavy metal distribution in some French forest soils: evidence for atmospheric contamination. Science of the Total Environment 312, 195-219. 
Jensen, N.P., Svensmark, B., 1989. Distribution and concentration of $\mathrm{Pb}$ and $\mathrm{Cd}$ in two adjacent luvisols under grassland and forest in Denmark. Zeitschrift für Pflanzenernährung und Bodenkunde 152, 121-124.

Kabala, C., Szerszen, L., 2002. Profile distributions of lead, zinc, and copper in Dystric Cambisols developed from granite and gneiss of the Sudetes Mountains, Poland. Water, Air, and Soil Pollution 138, 307-317.

Komárek, M., Chrastny, V., Ettler, V., Tlustoš, P., 2006. Evaluation of extraction/ digestion techniques used to determine lead isotopic compositions in forest soils. Analytical and Bioanalytical Chemistry 385, 1109-1115.

Kuo, S., Harsh, J.B., 1997. Physicochemical Characterization of Metals in Soil and Their Plant Availability. In: Adriano, D.C., Chen, Z.-S., Yang, S.-S., Isakandar, I.K. (Eds.), Biogeochemistry of Trace Metals. Advances in Environmental Science. Science Reviews, Northwood, England, pp. 75-120.

Labanowski, J., Monna, F., Bermond, A., Cambier, P., Fernandez, C., Lamy, I., van Oort, F., 2008. Kinetic extractions to assess mobilization of $\mathrm{Zn}, \mathrm{Pb}, \mathrm{Cu}$, and $\mathrm{Cd}$ in a metal-contaminated soil: EDTA vs. citrate. Environmental Pollution 152, 693 701.

Lamy, I., van Oort, F., Dère, C., Baize, D., 2006. Use of major- and trace-element correlations to assess metal migration in sandy Luvisols irrigated with wastewater. European Journal of Soil Science 57, 731-740.

Leguédois, S., van Oort, F., Jongmans, A.G., Chevallier, P., 2004. Morphology, chemistry and distribution of neoformed spherulites in agricultural land affected by metallurgical point-source pollution. Environmental Pollution 130, 135-148.

Lévêque, J., Phillippe, S., Baize, D., Monna, F., Haack, U., 2002. Utilisation des isotopes stables du plomb pour la détermination des sources de pollutions et l'étude de son transfert dans les sols contaminés. In: Baize, D., Tercé, M. (Eds.), Les Eléments métalliques dans les sols - Approches fonctionnelles et spatiales. INRAEditions, Versailles, France, pp. 375-391.

Monna, F., Loizeau, J.L., Thomas, B.A., Guéguen, C., Favarger, P.Y., 1998. Pb and S isotope measurements by inductively coupled plasma-mass spectrometer: efficient time management for precision improvement. Spectrochimica Acta 53 , 1317-1333.

Monna, F., Loizeau, J.L., Thomas, B., Guéguen, C., Favarger, P.Y., Losno, R., Dominik, J. 2000. Noise identification and sampling frequency determination for precise isotopic measurements by quadrupole-based inductively coupled plasma mass spectrometry. Analusis 28, 750-757.

Monna, F., Petit, C., Guillaumet, J.P., Jouffroy-Bapicot, I., Blanchot, C., Dominik, J, Losno, R., Richard, H., Lévèque, J., Chateau, C., 2004. History and environmental impact of mining activity in celtic aeduan territory recorded in peat bog (Morvan, France). Environmental Science \& Technology 38, 665-673.

Monna, F., Poujol, M., Losno, R., Dominik, J., Annegarn, H., Coetzee, H., 2006. Origin of atmospheric lead in Johannesburg, South Africa. Atmospheric Environment 40, 6554-6566.

Nahmani, J., Lavelle, P., Lapied, E., van Oort, F., 2003. Effects of heavy metal soil pollution on earthworm communities in the north of France. Pedobiologia 47 663-669.

van Oort, F., Balabane, M., Gaultier, J.P., Hardy, R., Bourennane, H., 2001. Dissemination and spatial variability of metal pollutants generated by past metallurgical activity of a zinc smelter complex in surrounding agricultural land (Mortagne-du-Nord, northern France). Mémoires des Sciences de la Terre 40, 157-160. van Oort, F., Gaultier, J.P., Hardy, R., Bourennane, H., 2002. Distributions spatiales de métaux et stratégies d'échantillonnage dans les sols du périmètre agricole d'une friche industrielle. In: Baize, D., Tercé, M. (Eds.), Les Eléments métalliques dans les sols - Approches fonctionnelles et spatiales. INRA-Editions, Versailles, France, pp. 281-297.

van Oort, F., Jongmans, A.G., Citeau, L., Lamy, I., Chevallier, P., 2006. Microscale Zn and $\mathrm{Pb}$ distribution patterns in subsurface soil horizons: an indication for metal transport dynamics. European Journal of Soil Science 57, 154-166.

van Oort, F., Thiry, M., Jongmans, T., Bourennane, H., Cambier, P., Lamy, I., Citeau, L., Fernandez, C., Nahmani, J. Les pollutions métalliques d'un site industriel et des sols environnants: distributions hétérogènes des métaux et relations avec l'usage des sols. In: Cambier, P., Schvartz, C., van Oort, F. (Eds.), Devenir et Effets des Contaminations Métalliques dans les Agrosystèmes et Ecosystèmes Terrestres Péri-industriels. Editions Quae, Versailles, France, in press.

Semlali, R., van Oort, F., Denaix, L., Loubet, M., 2001. Estimating distributions of endogenous and exogenous $\mathrm{Pb}$ in soils by using isotopic ratios. Environmental Science \& Technology 35, 4180-4188.

Semlali, R., Dessogne, J.B., Monna, F., Bolte, J., Azimi, S., Navarro, N., Denaix, L., Loubet, M., Chateau, C., van Oort, F., 2004. Modeling lead input and output in soils using lead isotopic geochemistry. Environmental Science \& Technology 38, 1513-1521.

Shotyk, W., Blaser, P., Grünig, A., Chebukin, A.K., 2000. A new approach for quantifying cumulative, anthropogenic, atmospheric lead deposition using peat cores from bogs: $\mathrm{Pb}$ in eight Swiss peat bog profiles. Science of the Total Environment 249, 281-295.

Spiro, S., Weiss, D.J., Purvis, O.W., Mikhailova, I., Williamson, B.J., Coles, B.J., Udachin, V., 2004. Lead isotopes in lichens transplants around a Cu smelter in Russia determined by MC-ICP-MS reveal transient records of multiple sources. Environmental Science \& Technology 38, 6522-6528.

Sterckeman, T., Douay, F., Proix, N., Fourrier, H., 2000. Vertical distribution of $\mathrm{Cd}, \mathrm{Pb}$ and $\mathrm{Zn}$ in soils near smelters in the North of France. Environmental Pollution 107, 377-389.

Sterckeman, T., Douay, F., Baize, D., Fourrier, H., Proix, N., Schvartz, C., 2006a. Trace elements in soils developed in sedimentary materials from Northern France. Geoderma 136, 912-929.

Sterckeman, T., Douay, F., Baize, D., Fourrier, H., Proix, N., Schvartz, C., Carignan, J., 2006b. Trace element distributions in soils developed in loess deposits from northern France. European Journal of Soil Science 57, 392-410.

Teutsch, N., Erel, Y., Halicz, L., Banin, A., 2001. Distribution of natural and anthropogenic lead in Mediterranean soils. Geochimica et Cosmochimica Acta 65, 2853-2864.

Thiry, M., Huet-Taillanter, S., Schmitt, J.M., 2002. La friche industrielle de Mortagnedu-Nord (59) - I. Prospection du site, composition des scories, hydrologie et estimation des flux. Bulletin de la Société Géologique de France 173, 369-381.

Véron, A., Flament, P., Bertho, M.L., Alleman, L., Flegal, R., Hamelin, B., 1999. Isotopic evidence of pollutant lead sources in Northwestern France. Atmospheric Environment 33, 3377-3388.

Watmough, S.A., Hutchinson, T.C., 2004. The quantification and distribution of pollution $\mathrm{Pb}$ at a woodland in rural south central Ontario, Canada. Environmental Pollution 128, 419-428.

Wedepohl, K.H., 1995. The composition of the continental crust. Geochimica et Cosmochimica Acta 59, 1217-1232. 